\title{
PENGEMBANGAN WEB SERVICE PROFIL JURUSAN DAN FAKULTAS (STUDI KASUS FAKULTAS TEKNIK DAN KEJURUAN UNDIKSHA)
}

\author{
I Gede Partha Sindu ${ }^{1)}$, Gede Saindra Santyadiputra ${ }^{2)}$ \\ ${ }^{1}$ Jurusan Pendidikan Teknik Informatika FTK UNDIKSHA \\ email: partha.sindu@undiksha.ac.id \\ 2 Jurusan Pendidikan Teknik Informatika FTK UNDIKSHA \\ email: gsaindras@undiksha.ac.id
}

\begin{abstract}
Abstrak
Perkembangan dan pemanfaatan Information and Communication Technology (ICT) dalam banyak bidang bukanlah hal yang baru saat ini. Pemanfaatan dan pengembangan ICT di berbagai bidang telah banyak membantu kerja dalam berbagai bidang termasuk bidang pendidikan. UNDIKSHA telah memiliki beberapa sistem informasi dengan memanfaatkan media website. Salah satu fakultas di lingkungan UNDIKSHA yang memanfaatkan media website dalam memberikan layanan informasi yaitu Fakultas teknik dan Kejuruan (FTK). Setiap jurusan di lingkungan FTK sudah memiliki sistem informasi berupa website jurusan yang masing-masing dikelola oleh jurusan. Namun belum ada suatu sistem atau Web Service yang mampu menangani dan menginterasikan sistem website yang tersedia di masing-masing jurusan. Penelitian ini bertujuan untuk mengembangkan suatu sistem terintegrasi berupa layanan Web Service yang menghubungkan semua sistem yang ada di lembaga ke dalam web profil jurusan dan fakultas. Model pengembangan yang digunakan pada penelitian ini adalah Software Development Life Cycle (SDLC). Hasil dari penelitian ini adalah web profil fakultas dan jurusan yang menyediakan Web Service dari berbagai sistem informasi yang terdapat di UNDIKSHA. Web Profil ini juga telah mampu mengimplementasikan web service untuk menunjang sinkronasi data antara web profil dengan data Center.
\end{abstract}

Kata kunci: sistem informasi, website, web service

\begin{abstract}
The development and use of Information and Communication Technology (ICT) in many areas is not new today. Utilization and development of ICT in various fields has helped many working in various fields including education. UNDIKSHA have had some system information by using media websites. One faculty in Undiksha the use of the media in providing information services website of the Faculty of engineering and Vocational (FTK). Each department within the FTK own department information system in the form of websites, each of which is managed by the department. But there is no system or Web Service is an integrated system capable of handling and websites that are available in each department. This research aims to develop an integrated system of services in the form of Web services that connect all the systems that exist in the body into a web profile departments and faculties. The development model used in this study is the Software Development Life Cycle (SDLC). The results of this study are web profiles faculties and departments that provide Web Service of systems of information contained in Undiksha. This profile Web has also been able to implement the web service to support the synchronization of data between a web profile with the data center.
\end{abstract}

Keywords : information systems, website, web service

\section{PENDAHULUAN}

Kemajuan teknologi informasi dan Internet tidak dapat dilepaskan dari bidang pendidikan. Dengan adanya internet dapat membuka sumber informasiyang tadinya susah diakses. Media online internet mulai 
dimanfaatkan untuk penunjang layanan sistem informasi akademik di berbagai universitas, salah satunya yaitu Universitas Pendidikan Ganesha (UNDIKSHA).Saat ini kebutuhan akan adanya sistem informasi akademik terintegrasi semakin meningkat, khususnya di level perguruan tinggi. Kondisi ini merupakan hal yang sangat wajar mengingat proses manajemen kampus bukanlah proses yang sederhana dan mudah. Apalagi di tengah semakin meningkatnya kesadaran masyarakat terhadap kebutuhan pendidikan hingga level perguruan tinggi, semakin 'memaksa' pihak manajemen perguruan tinggi untuk meningkatkan kualitas pendidikannya. Salah satu solusi yang ditempuh oleh mereka adalah pemanfaatan Teknologi Informasi dan Komunikasi (TIK). Dengan pemanfaatan TIK ini, pihak manajemen kampus berharap dapat semakin memberikan pelayanan dan kualitas pendidikan kepada civitas kampus dan masyarakat luas.

Universitas Pendidikan Ganesha dalam menunjang layanan informasi akademik, telah memiliki beberapa sistem informasi dengan memanfaatkan media website. Media Website ini menampilkan beberapa informasi tentang fakultas dan jurusan yang ada di Lingkungan UNDIKSHA. Salah satu fakultas di lingkungan UNDIKSHA yang memanfaatkan media website dalam memberikan layanan informasi yaitu Fakultas teknik dan Kejuruan (FTK). Fakultas teknik dan Kejuruan UNDIKSHA terdiri dari beberapa jurusan yaitu Jurusan Pendidikan Kesejahteraan Keluarga, D3 Manajemen Informatika, Pendidikan Teknik Elektro, D3 Teknik Elektro, Pendidikan Teknik Informatika, dan Pendidikan Teknik Mesin. Setiap jurusan di lingkungan FTK sudah memiliki sistem informasi berupa website jurusan yang masing-masing dikelola oleh jurusan. Namun belum ada suatu sistem atau Web Service yang mampu menangani dan menginterasikan sistem website yang tersedia di masing-masing jurusan. Menurut Scott (2001) dalam penelitian Rifai Katili, integrasi sistem didefinisikan sebagai adanya saling keterkaitan antar sistem sehingga data dari satu sistem secara rutin dapat melintas menuju atau diambil oleh satu atau lebih sistem yang lain. Penggunaan TIK dalam proses manajemen kampus dilakukan dengan memanfaatkan pengembangan sistem informasi akademik terintegrasi. Dalam implementasi pengembangan sistem terintegrasi di level perguruan tinggi, ada beberapa ruang lingkup yang harus diintegrasikan satu dengan yang lainnya. Masing-masing ruang lingkup memiliki sistemnya sendiri. Namun, dalam sistem terintegrasi ruang lingkup tersebut akan disatukan dalam suatu proses manajemen yang saling berkaitan sehingga memudahkan dalam proses pengambilan data.

Saat ini website yang dikelola di masingmasing jurusan di lingkungan Fakultas Teknik dan Kejuruan UNDIKSHA belum tersedia link ke beberapa sistem di lembaga. Permasalahan lainnya adalah belum adanya suatu layanan pada website di masing-masing jurusan FTK yang mampu menampilkan jumlah data mahasiswa, data pendukung kemahasiswaan, data dosen, data pustaka dan repository, penelitian pengabdian dan publikasi, perlengkapan (E-inventory), sasaran kinerja pegawai (SKP), beban kerja dosen (BKD), penawaran dan penjadwalan mata kuliah. Akibat belum terintegrasinya semua layanan ini, menyebabkan mahasiswa, dosen dan pegawai di lingkungan FTK mengalami kesulitan dalam proses pengambilan data dan informasi.

Banyak penelitian yang dilakukan bagaimana menangani dan menginterasikan sistem website dengan menggunakan web service. Menurut Kreger (dalam Priyambodo, 2005) Web Service diartikan sebagai sebuah antar muka (interface) yang menggambarkan sekumpulan operasi-operasi yang dapat diakses melalui jaringan, misalnya internet, dalam bentuk pesan XML. Web Service adalah suatu sistem perangkat lunak yang dirancang untuk mendukung interoperabilitas dan interaksi antar sistem pada suatu jaringan. Web Service digunakan sebagai suatu fasilitas yangdisediakan oleh suatu web site untuk 
menyediakan layanan (dalam bentuk informasi) kepada sistem lain, sehingga sistem lain dapat berinteraksi dengan sistem tersebut melalui layanan-layanan (service) yang disediakan oleh suatu sistem yang menyediakan Web Service. Tujuan Web Service adalah meningkatkan kolaborasi antar aplikasi,dimana terdapat suatu fungsi yang ada di dalam Web Service yang dapat digunakan oleh aplikasi lain tanpa perlu mengetahui isi dari program yang dipanggil.

Menurut penelitian yang dilakukan oleh Wijaya (2015), penerapan Web Service pada aplikasi sistem akademik pada platform sistem operasi mobile android memudahkan mahasiswa dan dosen dalam mendapatkan layanan informasi akademik. Di sisi lain, penelitian yang dilakukan oleh Priyambodo (2005), tentang implementasi Web Service untuk sistem infomasi kepariwisataan terpadu sangat membantu wisatawan dalam mengakses obyek-obyek wisata di propinsi Jawa Tengah dan Daerah Istimewa Yogyakarta. Penelitian ini mengembangkan dua buah webservice yaitu Web Service WisataBudayaJawa yang berfungsi untuk memberikan rekomendasi obyek-obyek wisata di propinsi Jawa Tengah dan Daerah Istimewa Yogyakarta, dan web service. Kurs yang berfungsi untuk memberikan informasi harian mengenai nilai tukar sejumlah mata uang asing terhadap mata uang rupiah. Kedua Web Service tersebut saling diintegrasikan untuk memberikan gambaran mengenai sistem multi-tier serta dimanfaatkan untuk membangun sebuah program aplikasi web. Penelitian lainnya, menurut Anggrainingsih et al. (2012), penerapan sistem informasi yang terintegrasi akan memperbaiki kinerja utama Jurusan dan membantu proses pertukaran dan pengiriman data antar bagian menjadi cepat.

Berdasarkan hal tersebut maka perlu dikembangkan suatu sistem terintegrasi berupa layanan Web Service yang menghubungkan semua sistem yang ada di lembaga ke dalam web profil jurusan dan fakultas. Hasil dari penelitian ini adalah web profil fakultas dan jurusan yang menyediakan Web Service dari berbagai sistem informasi yang terdapat di UNDIKSHA.

\section{METODE}

Model pengembangan yang digunakan pada penelitian ini adalah Software Development Life Cycle (SDLC). Terdapat 5 tahapan dalam SDLC, diantaranya adalah perencanaan, analisis, perancangan, implementasi, serta ujicoba dan evaluasi. Adapun 5 tahapan dari metode dapat dilihat pada Gambar 1 .

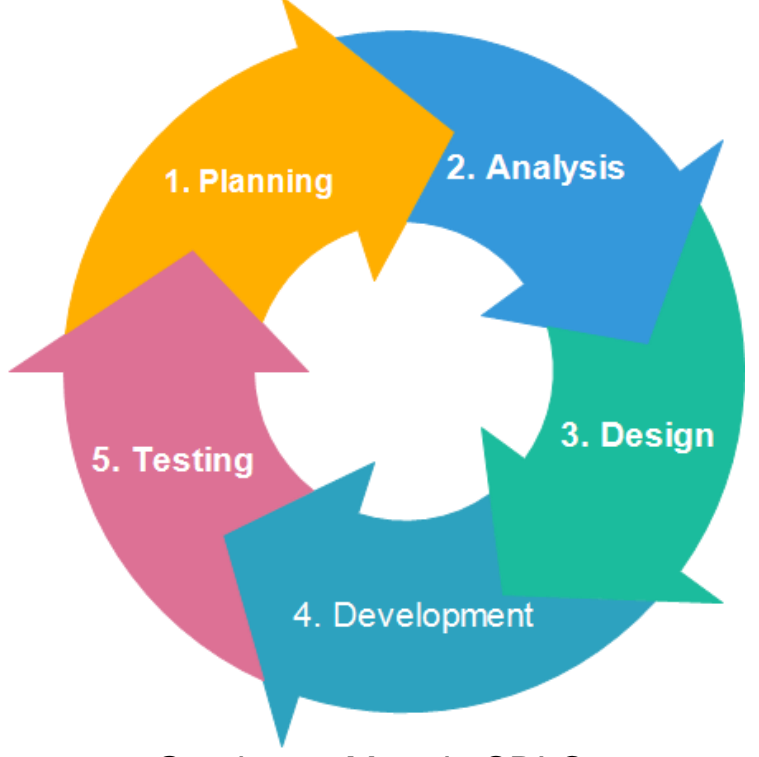

Gambar 1. Metode SDLC

Identifikasi permasalahan dilakukan di tahapan perencanaan. Permasalahan tersebut dirumuskan ke dalam rumusan permasalahan dan tujuan pengembangan sistem. Studi kebutuhan pengembangan juga dilakukan di tahapan ini. Keluaran dari tahapan perencanaan adalah berupa proposal penelitian yang berisi rencana pengembangan, tinjauan pustaka dan kebutuhan sumber daya.

Tahapan analisis berisi proses analisis kebutuhan sistem dan menentukan solusi pengembangan terbaik. Terdapat beberapa proses analisis yang dilakukan pada tahapan ini, diantaranya adalah analisis kebutuhan fungsional, analisis kebutuhan nonfungsional, penentuan dan pemilihan solusi, serta analisis batasan sistem. Analisis kebutuhan fungsional dilakukan untuk menentukan fungsi-fungsi apa saja yang ada pada sistem. Analisis non- 
fungsional dilakukan untuk menentukan kebutuhan lainnya seperti kebutuhan perangkat lunak dan perangkat keras. Selanjutnya adalah menentukan alternatif solusi pengembangan berdasarkan analisis fungsional dan non-fungsional dan memilih salah satu solusi pengembangan terbaik beserta dengan batasan sistem yang akan dikembangkan. Keluaran dari tahapan ini adalah laporan cakupan sistem yang akan dikembangkan.

Perancangan sistem dilakukan berdasarkan pada hasil dari tahapan analisis. Terdapat tiga rancangan yang dibuat pada penelitian ini, yaitu 1) rancangan sistem Web Service profil jurusan dan fakultas di lingkungan FTK. 2) Rancangan keluaran sistem, dimana keluaran sistem ini akan berupa layanan Web Service yang menghubungkan semua sistem yang ada di lembaga ke dalam web profil jurusan dan fakultas. 3) Rancangan antar muka dari sistem Web Service profil jurusan dan fakultas di lingkungan FTK. Model perancangan yang digunakan adalah Unified Modeling Language (UML).

Implementasi sistem dilakukan berdasarkan pada rancangan sistem yang dilakukan pada tahapan perancangan. Pembuatan sistem sinkronisasi video dan slide akan dilakukan dengan menggunakan bahasa pemrograman PHP. Rancangan keluaran sistem akan diimplementasikan menggunakan teknologi HTML5 dan CSS3 agar dapat diakses dari berbagai perangkat melalui web browser melalui komputer, smart phone maupun tablet yang mendukung teknologi tersebut. Keluaran dari tahapan ini adalah berupa prototipe sistem Web Service profil jurusan dan fakultas di lingkungan FTK.

Uji coba dan evaluasi dilakukan setelah implementasi sistem selesai dilakukan. Pada tahapan ini, sistem Web Service yang dikembangkan akan diujicobakan ke semua website jurusan dan fakultas di lingkungan FTK. Hasil uji coba ini akan melihat sejauh mana sistem melayani permintaan user terkait dengan data sistem informasi Pangkalan Data Dosen (PDD), pustaka dan repository, data kemahasiswaan, penelitian pengabdian dan publikasi, sistem borang, pendukung data kemahasiswaan, penelitian pengabdian dan publikasi, perlengkapan (E-inventory), Sasaran Kinerja Pegawai (SKP), Beban Kerja Dosen (BKD), penawaran dan penjadwalan mata kuliah. Metode black box testing akan digunakan untuk melakukan evaluasi sistem maupun keluarannya. Pengujian dilakukan melalui web browser yang ada pada komputer, smartphone, dan komputer tablet. Pada rancangan sistem menggambarkan garis besar dari pemodelan fungsional sistem dan analisis aliran data atau informasi pada sistem yang akan dikembangkan. Sistem Informasi Profil Jurusan dan Fakultas dikembangkan menggunakan pemodelan Data Flow Diagram (DFD). Sistem Informasi Profil Jurusan dan Fakultas ini dibuat menggunakan DFD untuk menggambarkan aliran datanya. Aliran data secara umum yang digambarkan dalam Diagram Konteks dapat dilihat pada Gambar 2.

\section{HASIL DAN PEMBAHASAN}

Proses hasil penelitian ini sudah menghasilkan Sistem Informasi Profil Jurusan dan Fakultas yang dibangun menggunakan teknologi berbasis web dengan bahasa pemrograman PHP dan basis data MySQL. Pengujian sistem ditempuh dengan menggunakan pendekatan Whitebox dan Blackbox testing. Dimana whitebox testing dilakukan untuk memverifikasi kebenaran alur algoritma dan struktur data dari sistem yang dibuat, sementara Blackbox testing dilakukan memverifikasi kebenaran fungsionalitas sistem berdasarkan hasil analisis kebutuhan.

Adapun screenshot dari tampilan sistem informasi dan basis data yang dirancang adalah seperti tampak pada Gambar 2, 3, 4 dan 5. 


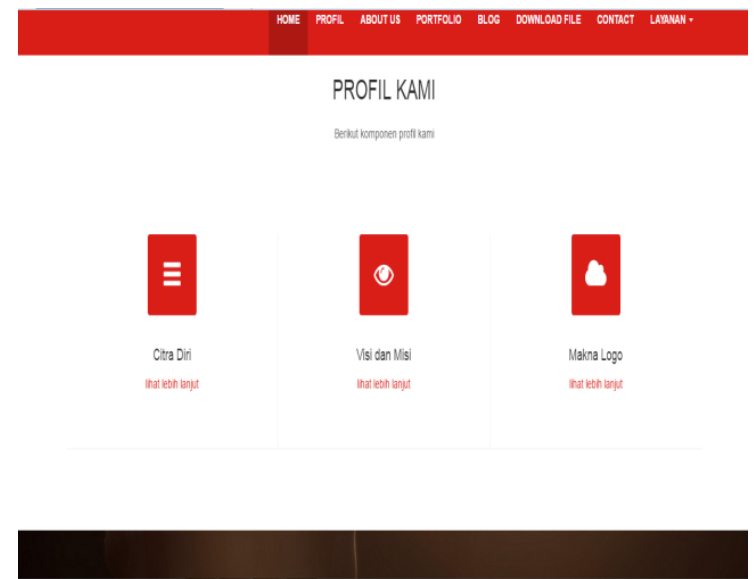

Gambar 2. Tampilan Sistem Informasi

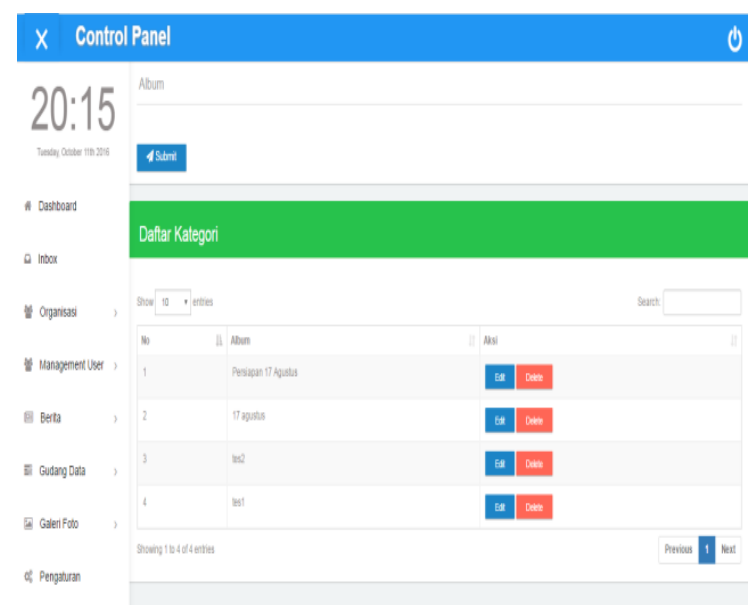

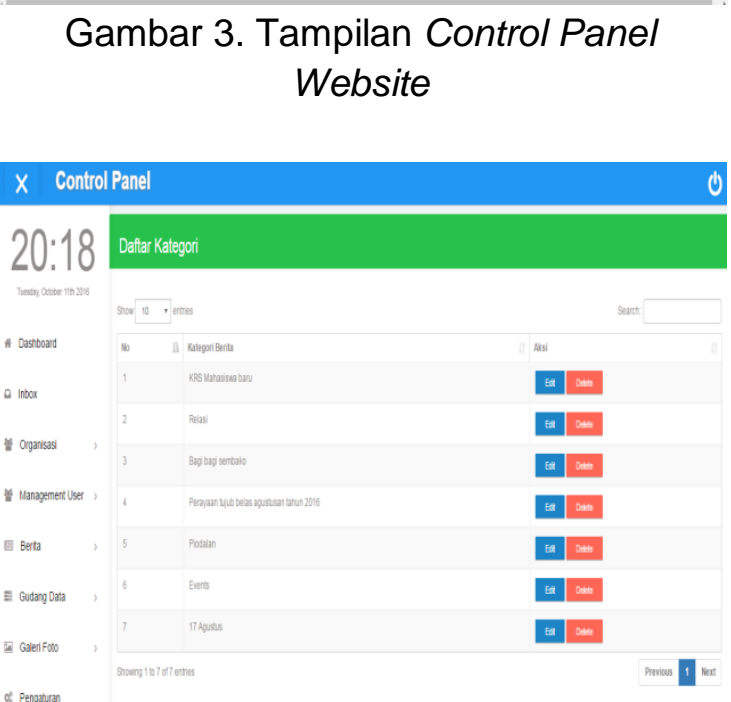

Gambar 4. Tampilan setelah klik menu

Edit, dan Delete Data di dalam data Kategori Berita

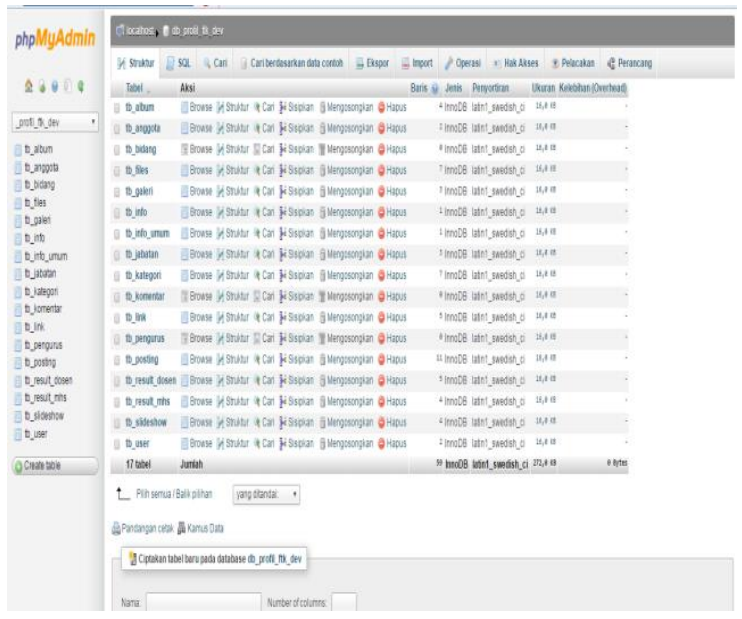

Gambar 5 Tampilan Basis Data

\section{Implementasi Web Service Pada Web Profil Jurusan dan Fakultas}

Untuk pemanggilan web service user masuk ke panel root, pada side bar pilih menu Sync to $D C$, selanjutnya akan muncul beberapa pilihan sinkronasi seperti Gambar 6.

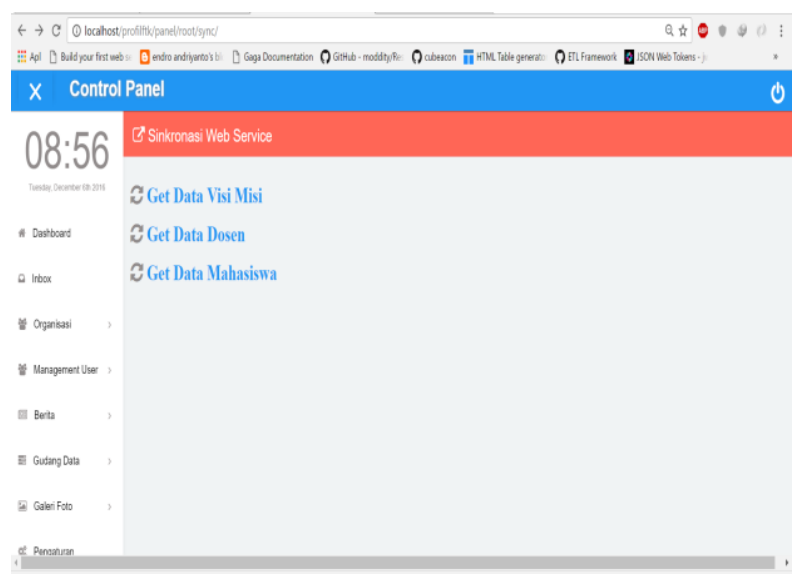

Gambar 6. Panel Konfigurasi Sinkronasi Data

Jika user meng-klik Get data Dosen maka web service akan memasukkan data dosen secara otomatis ke database local web profil. Prosesnya bisa dilihat pada gambar 7. 

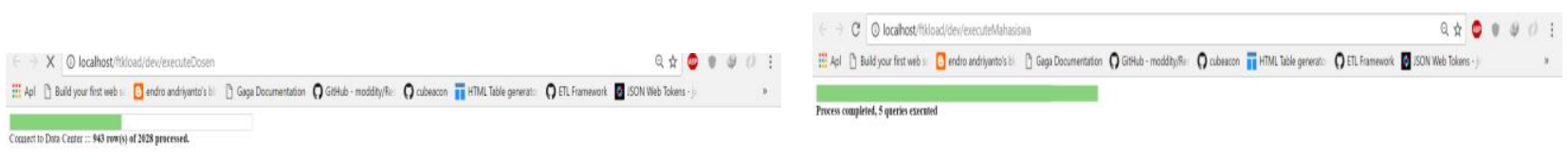

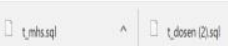

\section{Gambar 7. Proses Sinkronasi Data Dosen}

Setelah berhasil memasukan data dosen ke database local profil FTK, maka muncul tampilan pada gambar 8 .

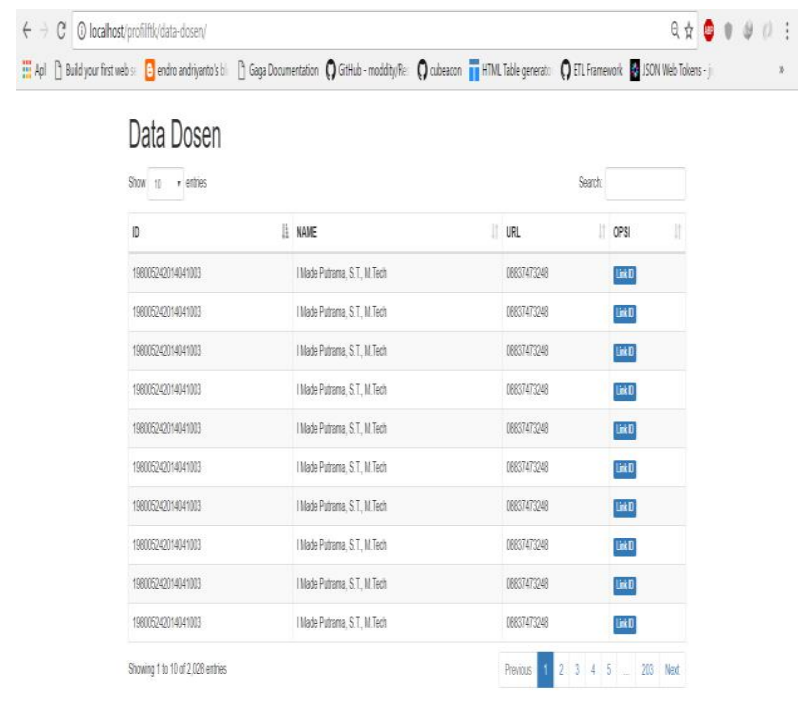

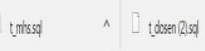

\section{Gambar 8. Hasil Sinkronasi Data Dosen}

Jika user meng-klik Get data Mahasiswa maka web service akan memasukkan data mahasiswa secara otomatis ke database local web profil. Prosesnya pada gambar 9.
Gambar 9. Proses Sinkronisasi Data Mahasiswa

Setelah berhasil memasukan data mahasiswa ke database local profil FTK, maka muncul tampilan pada gambar 10 .

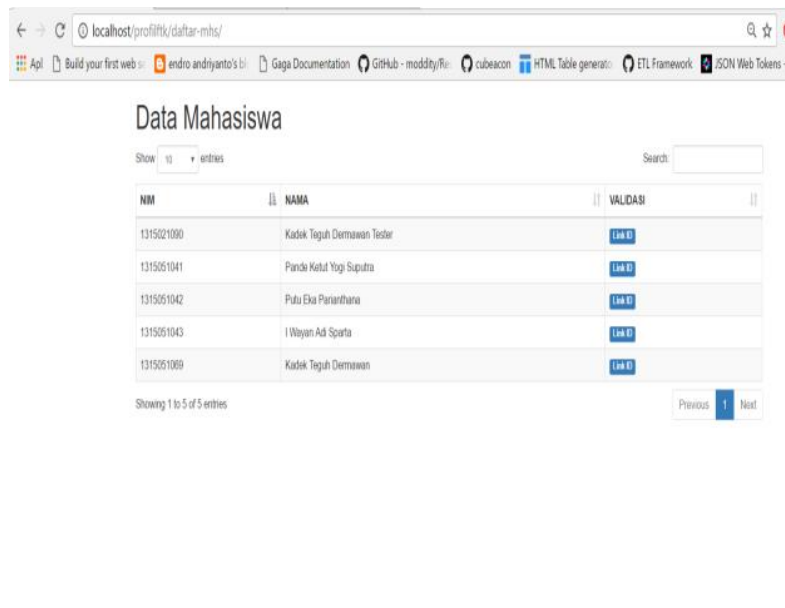

Q tuitsal

Gambar 10. Hasil Sinkronisasi Data Mahasiswa

Jika user meng-klik Get data Visi Misi maka web service akan memasukkan data visi misi secara otomatis ke database local web profil. Prosesnya bisa dilihat pada gambar 11. 


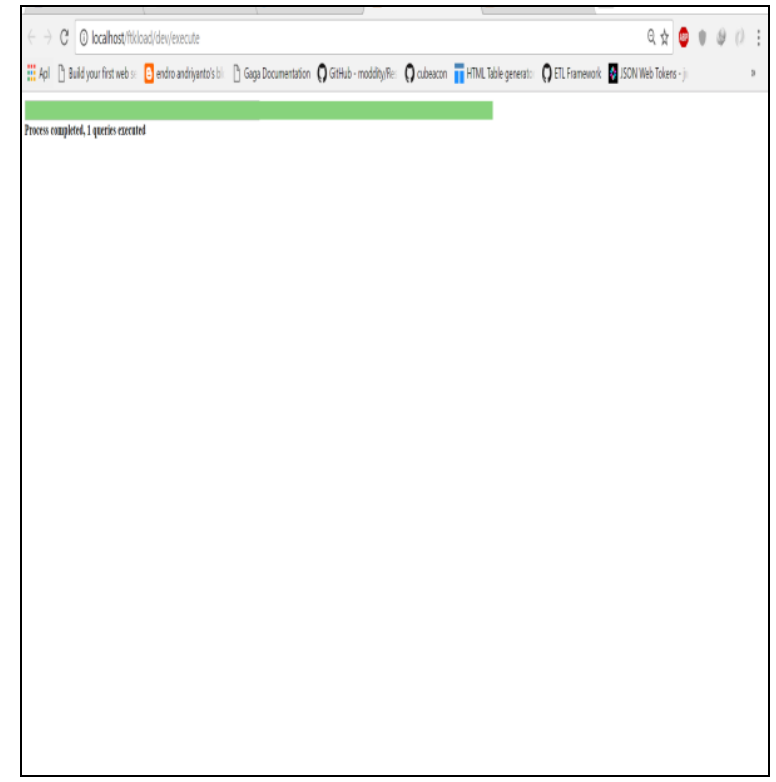

Gambar 11. Proses Sinkronisasi Data Visi Misi

Setelah berhasil memasukan data mahasiswa ke database local profil FTK, maka muncul tampilan pada gambar 12 .

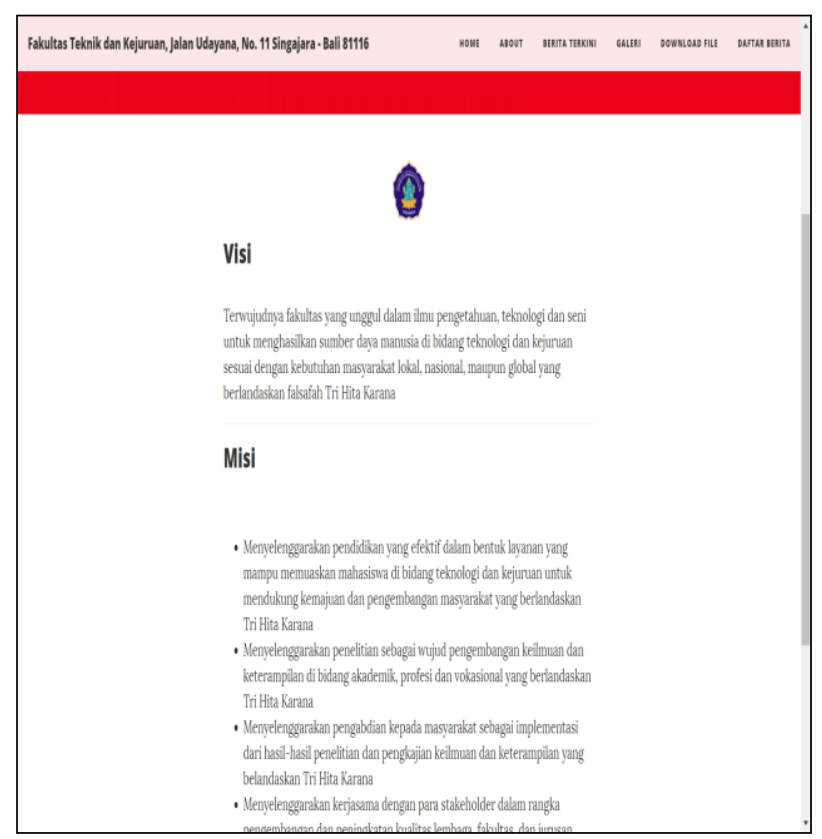

Gambar 12 Hasil Sinkronisasi Data Mahasiswa

Berikut adalah cuplikan code yang digunakan untuk tahap proses pengambilan data dosen melalui web service ke database local FTK. Source Code Sinkronisasi Data dapat dilihat pada Gambar 13.

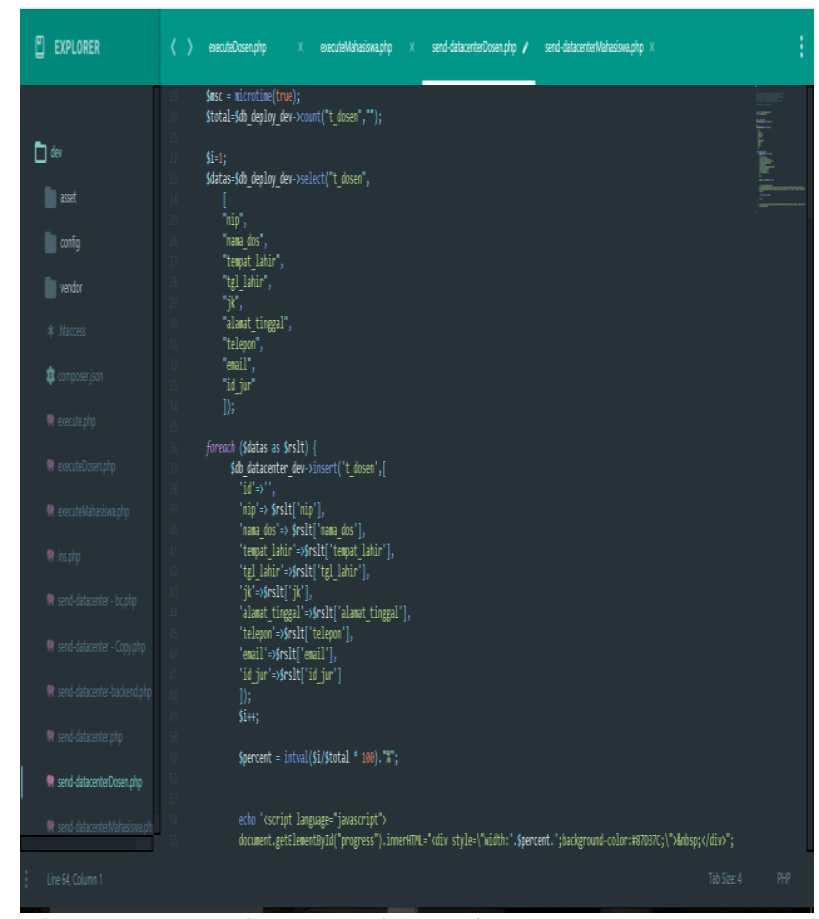

Gambar 13 Source Code Sinkronasi Data Dosen dengan Web Service

Berikut adalah cuplikan code yang digunakan untuk tahap proses pengambilan data mahasiswa melalui web service ke database lokal FTK. Adapun cuplikan Kode yang digunakan dapat dilihat pada Gambar 14.

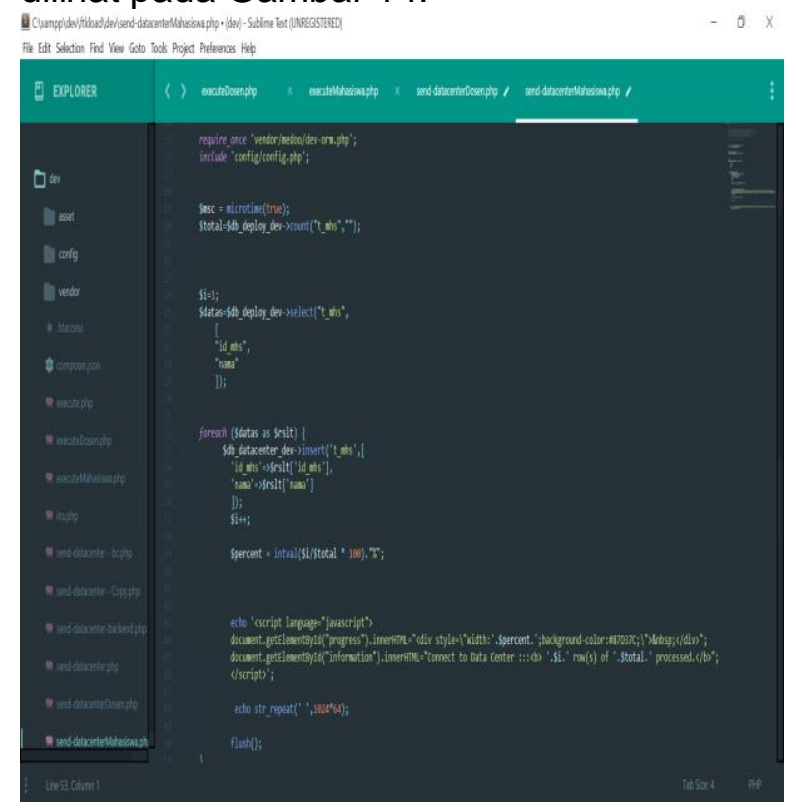

Gambar 14. Source Code Sinkronasi Data Mahasiswa dengan Web Service 
Pada Gambar 15 berikut adalah cuplikan code yang digunakan untuk tahap proses pengambilan data visi misi melalui web service ke database local FTK.

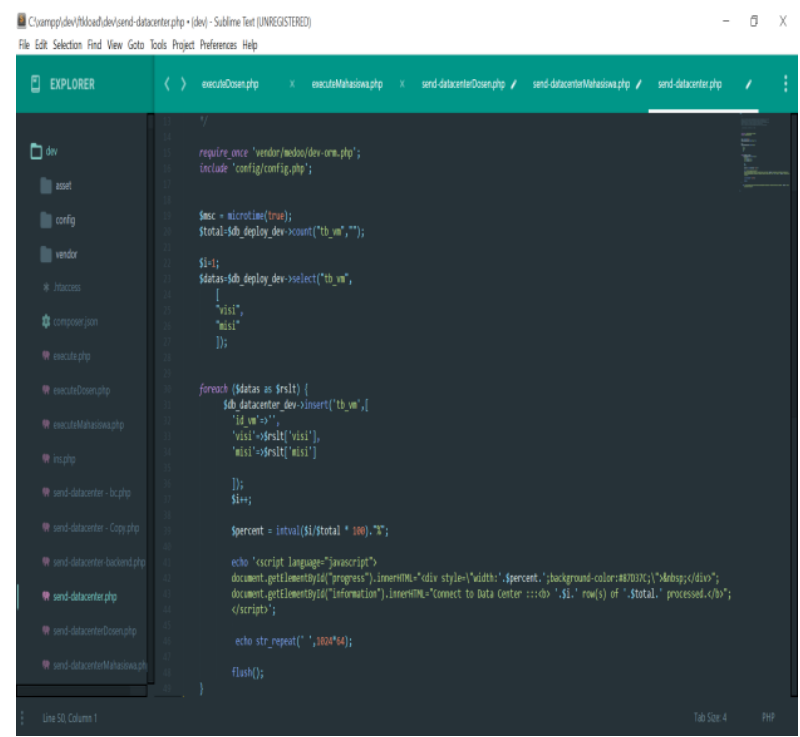

Gambar 15 Source Code Sinkronasi Data

Visi Misi dengan Web Service

Berikut ini yaitu Gambar 16 adalah tampilan hasil pengujian kiriman data dosen dari web service menuju end point

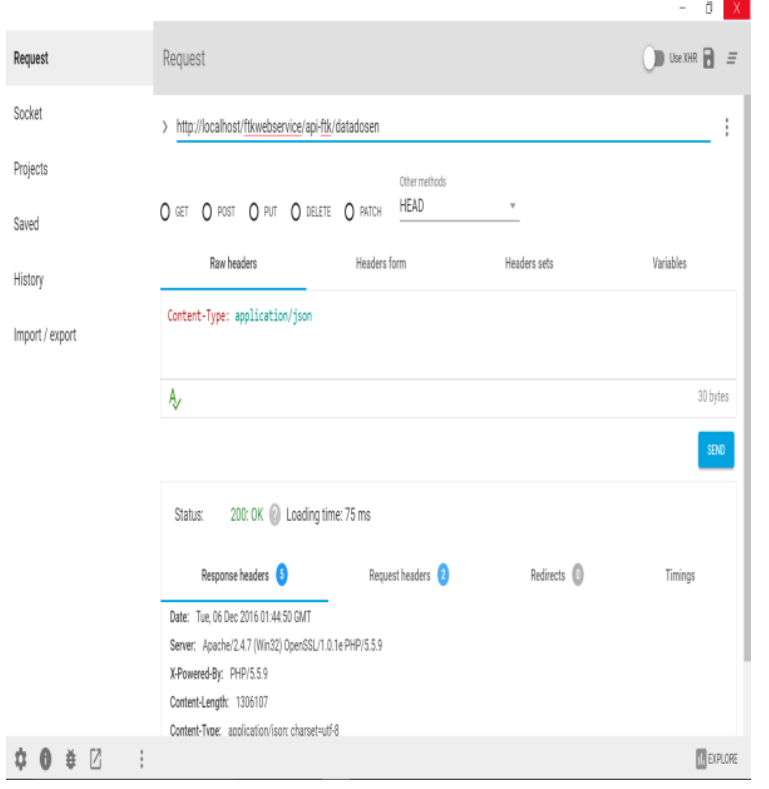

Gambar 16 Pengujian Web Service Data

Dosen

Berikut ini pada Gambar 17 adalah tampilan hasil pengujian kiriman data mahasiswa dari web service menuju end point

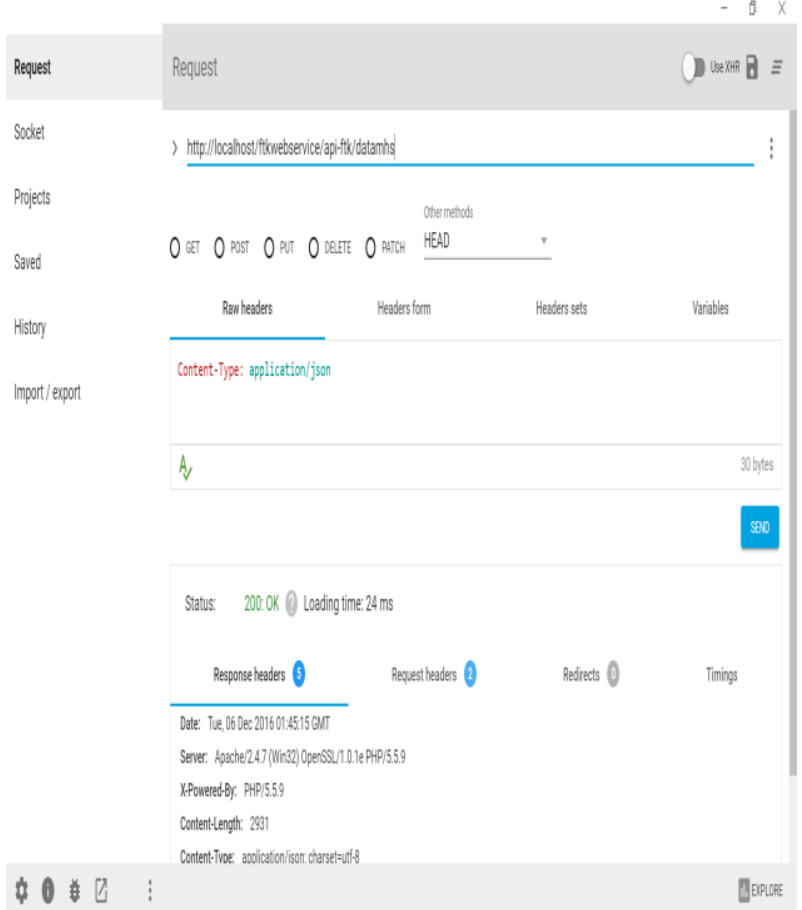

Gambar 17 Pengujian Web Service Data

Mahasiswa

Berikut ini pada Gambar 18 adalah tampilan hasil pengujian kiriman data visi misi dari web service menuju end point 


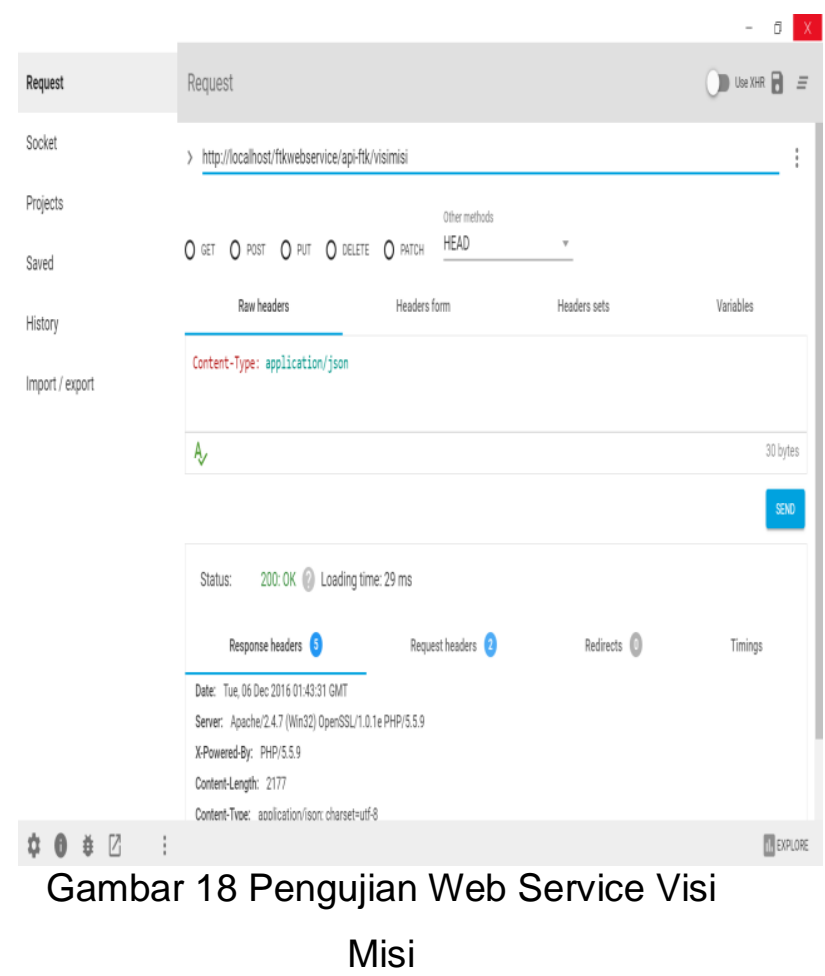

\section{SIMPULAN DAN SARAN}

Kesimpulan dari kegiatan penelitian yang dilakukan adalah sebagai berikut:

1. Pada tahap analisa kebutuhan telah dicapai berupa analisa kebutuhan data dan analisa kebutuhan proses pada website Sistem Informasi Profil Jurusan dan Fakultas.

2. Pada tahap perancangan model telah dihasilkan Aliran data secara umum yang digambarkan dalam Diagram Konteks dan Data Flow Diagram (DFD).

3. Pada Tahap Optimasi Website (Performa, Service dan Security) sudah di tambahkan pada Sistem Informasi Profil Jurusan dan Fakultas. Pengaturan Role User yang berfungsi untuk mengatur akses user sudah di tambahkan pada sistem ini.

4. Telah mampu mengimplementasikan web service untuk menunjang sinkronasi data antara web profil dengan data Center

\section{Saran}

Perlu pengembangan lebih lanjut lagi untuk penyediaan web service yang support ke semua CMS (Content Management System)

\section{UCAPAN TERIMAKASIH}

Tim peneliti mengucapkan terima kasih kepada Fakultas Teknik dan Kejuruan yang telah mendukung dan menyetujui penelitian ini. Terima kasih juga kami sampaikan kepada Jurusan Pendidikan Teknik Informatika yang selalu support terhadap penelitian dosen.

\section{DAFTAR PUSTAKA}

Anggrainingsih, R., Sihwi, S. W. \& Aziz, A. 2012. Kajian Penerapan Sistem Informasi Terintegrasi di Jurusan Informatika, FMIPA, Universitas Sebelas Maret. JURNAL ITSMART. Tersedia pada: https://jurnal.uns.ac.id/ index.php?journal=itsmart\&page $=$ arti cle\&op=download\&path $\% 5 \mathrm{~B} \% 5 \mathrm{D}=5$ 84\&path\%5B\%5D=536

Hamdani. 2011. Apa ituWeb Service. Sumber :http://hamdani.blog.ugm.ac. id/2011/07/15/apa-itu-web-service/

Muslim, M. A. 2012. Pengembangan Sistem Informasi Jurusan Berbasis Web Untuk Meningkatkan Pelayanan dan Akses Informasi. Jurnal MIPA 35. Tersedia pada http://journal.

unnes.ac.id/nju/index.php/JM/article/ download2101/2214

Priyambodo, T. K. 2005. Implementasi Web-Service Untuk Pengembangan Sistem Layanan Pariwisata Terpadu. Seminar Nasional Aplikasi Teknologi Informasi. Tersedia pada: http://www.jurnal.uii.ac.id/index.php/ Snati/article/download/1311/1071 
Wijaya, I W. G. S. 2015. Penerapan Web Service Pada Aplikasi Sistem Akademik Pada Platform Sistem Operasi Mobile Android. Sumber: http://server2.docfoc.us/uploads/Z20 15/12/12/h6pVJVCY4E/140395007c $8831 \mathrm{~d} 92$ 